\title{
Précis of Nietzsche's Constructivism: A Metaphysics of Material Objects (Routledge, 2018)
}

\author{
Justin Remhof ${ }^{1}$
}

Received: 4 October 2019 / Revised: 20 March 2020 / Accepted: 27 May 2020/

Published online: 8 October 2020

(C) Springer Nature B.V. 2020

In this book I set out to provide a comprehensive account of Nietzsche's material object metaphysics and argue that he is a constructivist. Constructivism is the neo-Kantian view that our representational practices bring all concrete objects into existence. This reading of Nietzsche is not brand-new in the literature. But it is certainly not mainstream. And constructivism is a contentious view of objects in its own right - the position strikes most readers as either flat-out false or too controversial for comfort. Perhaps this is why Nietzsche's constructivism has never been systematically explained or defended. As I see things, however, once Nietzsche's view is properly explicated his position is much stronger than it might initially seem to be, and I think reading Nietzsche as a constructivist can help illuminate key areas of his philosophical program as a whole.

The book starts by challenging alternative readings of Nietzsche's view of objects. Some believe that he is a commonsense realist (Clark 1990; Leiter 1994, 2002). Others hold that he is an eliminativist (Nola 1999; Meyer 2011). Some argue that he reconceives objects as bundles of forces, or more simply, bundles of empirical properties. One version of this view, unificationism, holds that bundles are unified intrinsically (Hales and Welshon 2000; Doyle 2009). Another version, constructivism, holds that bundles are unified extrinsically, specifically though human representational practices. I defend this last reading.

On my view, Nietzsche holds that objects are conceptually unified bundles of empirical properties. Planets, for instance, are bundles of properties the concept $<$ planet $>$ refers to, namely, objects that orbit the sun, remain round, and are gravitationally dominant. The world is filled with various clusters of properties, Nietzsche thinks, but no cluster is a formal unity — and thus a bona fide object — apart from our representational practices. This view of objects, I argue, best fits Nietzsche's texts. From early to late, Nietzsche repeatedly claims that objects are ontologically dependent on human actions. Commonsense realism, eliminativism, and unificationism all deny such dependence. Hence none get Nietzsche right.

Justin Remhof

jremhof@odu.edu

1 Department of Philosophy and Religious Studies, Old Dominion University,

Norfolk 23529 VA, USA 
Constructivism does not imply that we can simply create objects at will, or that the existence of objects depends merely on subjective preferences, or that with respect to what objects exist anything goes. Nietzsche places significant constraints on construction, though no constraint uniquely determines what is or can be constructed. Most importantly, object construction depends on empirical properties that can be encountered in experience. Objects are bundles of properties that we have sensible access to. Other constraints on construction include the experience of resistance, the current body of accepted beliefs, the fact that construction is a social phenomenon, and epistemic values like consistency, utility, and scope. These constraints rein in subjectivism and facile forms of relativism.

The fact that Nietzsche's constructivism is heavily constrained does not mean that the position comes without serious objections. Perhaps the most pressing objection is that constructivism, Nietzsche's or otherwise, is bankrupt because it cannot account for unperceived objects, most notably objects in the past. It is obvious that dinosaurs roamed the earth prior to the existence of human representational practices, for instance, and so it appears false that our practices bring dinosaurs into existence.

I suggest that Nietzsche can respond to this worry by drawing on Kant's view that reality is that which we can in principle encounter in experience. To say that velociraptors existed, for example, is to say that we can track a causal chain from something we perceive in the present-perhaps the perception of some recently uncovered fossils - back to when the application conditions for the concept <velociraptor $>$ are met. And, crucially, we play a constitutive role in determining these conditions.We decide which group of identifying properties $<$ velociraptor $>$ bundles. These properties include being a bipedal feathered carnivore in the Cretaceous period. The specific group of properties that constitute objects like velociraptors are brought together through our conceptual organization of the world, past or present. This allows Nietzsche to say that objects in the past are constructed.

Another objection concerns bootstrapping. Nietzsche holds that we bring objects into existence. One might argue, however, that we are also objects. It therefore seems that objects bring objects into existence, which appears absurd. I think Nietzsche's response is to explain away the problem. For Nietzsche, we gain determinate conditions of identity as we attempt to understand who we are in experience, from evolved organisms, to moral persons, to mothers and fathers. If this is accurate, then there seems to be no problem in claiming that we construct objects and we are constructed in turn.

Understanding that Nietzsche is a constructivist enables us to gain a better understanding of other important aspects of his philosophical project. Consider his views of truth and science, for instance. It is more or less standard to believe that Nietzsche rejects the pragmatist view that truth consists in beliefs that work given our interests. I suggest that Nietzsche endorses what William James and F. C. S. Schiller call a "humanist" view of truth. On this view, truths concerning concrete objects are constructed because the objects of reference of our true and false propositions that populate the empirical world are constructed. Nietzsche embraces a pragmatist understanding of truth in the sense that propositions pertaining to the empirical world gain a truthevaluable status only in relation to our interests.

Nietzsche's view of science is even more controversial. Commentators disagree over whether Nietzsche thinks science can represent the facts about the world. Some believe 
that Nietzsche takes science to be successful because it represents the mindindependent world. Others believe that he rejects the possibility of successful science altogether. I argue that Nietzsche's praise of science rests on accepting constructivism. It is a short path from constructivism about objects to constructivism about facts. Nietzsche seems to think a fact is just an object instantiating a property, and if so, then determining which properties constitute objects determines the facts about the empirical world. Science can successfully represent the world, then, and success turns on conceiving facts as mind-dependent.

Why might Nietzsche be motivated to embrace such a controversial view of facts and objects? I think his motivation lies in overcoming what worries him most: the advent of nihilism. For Nietzsche nihilism is the position that life is meaningless because our highest values cannot be realized in this world. One such value is what Nietzsche calls the "true world," that is, some world ontologically independent of the empirical world. From Plato and the Forms to Christianity and the Kingdom of Heaven, Nietzsche thinks humans have most often turned to the true world to find life meaningful. Even those who dedicate their lives to science and philosophy, Nietzsche argues, have been seduced into valuing the true world. Scientists and philosophers commonly believe that our best theories should be those that represent constitutively mind-independent facts and objects.

Constructivism renders this goal unattainable. Coming to recognize the truth of constructivism therefore enables us to see that a longstanding goal of scientific and philosophical inquiry cannot be realized in the conditions of this world. Constructivism even rejuvenates our cognitive aims with new purpose, which helps us overcome nihilism concerning our theoretical projects. Constructivism is not merely a metaphysical position, then, but a metaphysical position with vital practical consequencesconsequences that other readings of Nietzsche's view of objects (common sense realism, eliminativism, and unificationism) are not in a position to enjoy. In fact, by denying the constitutive dependence between objects and human practices, the other readings are essentially nihilistic.

The book's penultimate chapter compares and contrasts Nietzsche's constructivism with seemingly similar versions offered by those in the American pragmatist tradition, namely, William James, Nelson Goodman, and Richard Rorty. I argue that Nietzsche is closest to James and furthest from Rorty. The book finishes with an examination of how Nietzsche's constructivism might resolve difficult problems in analytic material object metaphysics, specifically the argument from vagueness, arbitrariness arguments, debunking arguments, and arguments concerning indeterminate identity. Most metaphysicians today reject the commonsense idea that what objects exist are those we typically take to exist, such as dogs and cats, planets and moons, and the like. Instead they believe that there are either indefinitely many objects right before our eyes (permissivism) or no objects (eliminativism). Both of these options should strike us as extremely bizarre. I argue that Nietzsche's constructivism provides a principled, unique way to defend this view.

For example, consider how a constructivist might respond to a common argument from arbitrariness. Permissivists might claim that incars exist because islands exist. Incars are cars that only exist in garages. They go out of existence when leaving a garage, similar to the way in which we might say that islands go out of existence when completely submerged in water. This similarity leads 
permissivists to claim that there is no ontologically significant difference between islands and incars. Consequently, it seems objectionably arbitrary to accept the existence of islands but not incars.

The constructivist, however, can say that there is indeed an ontologically significant difference: we take there to be islands and no incars. This sounds simple, but the reasoning is neither obvious nor philosophically shallow. The constructivist argues that there are no unique bundles of properties in the world that require reference by way of extraordinary concepts like <incar>. The identity conditions of incars can be sufficiently picked out using familiar concepts like <car $>$, <garage $>$, and so on, and <island $>$ is just another of these ordinary concepts. This is just one way constructivism offers a principled way to take back a world that has slipped through the fingers of many analytic metaphysicians.

But - and I will finish with this - Nietzsche's constructivism is flexible, and for the better. Nietzsche is certainly not trapped into defending common sense ontologies. Constructivism can adapt with the times. Nietzsche simply denies that any particular conceptual scheme has the ability to represent the way objects are tenselessly and timelessly. Our concepts, which fix the conditions of identity of objects, develop and change in relation to our needs, interests, and purposes. Given our perennial interest in understanding the nature of objects that shape our perception of the world-from gendered bodies, to invasive species, to artificially intelligent entities - the ability to permit significant change, and sometimes even radical change, might be the most valuable quality of Nietzsche's constructivism.

\section{References}

Clark, M. (1990). Nietzsche on truth and philosophy. Cambridge: Cambridge University Press.

Doyle, T. (2009). Nietzsche on epistemology and metaphysics. Edinburgh: Edinburgh University Press.

Hales, S. D., \& Welshon, R. (2000). Nietzsche's perspectivism. Urbana: University of Illinois Press.

Leiter, B. (1994). Perspectivism in Nietzsche's genealogy of morals. In R. Schacht (Ed.), Nietzsche, genealogy, morality: Essays on Nietzsche's “on the genealogy of morals” (pp. 334-357). Berkeley: University of California Press.

Leiter, B. (2002). Nietzsche on morality. New York: Routledge.

Meyer, M. (2011). Naturalism and the falsification thesis. In H. Heit, G. Abel, \& M. Brusotti (Eds.), Nietzsche's Wissenschaftsphilosophie (pp. 133-146). Berlin: Walter de Gruyter.

Nola, R. (1999). Nietzsche's naturalism: Science and belief. In B. Babette \& R. Cohen (Eds.), Nietzsche, epistemology, and philosophy of science (pp. 91-100). Dordrecht: Kluwer Academic Publishers.

Publisher's Note Springer Nature remains neutral with regard to jurisdictional claims in published maps and institutional affiliations. 